\title{
LEVERAGING FIRM PERFORMANCE THROUGH INFORMATION TECHNOLOGY STRATEGIC ALIGNMENT AND KNOWLEDGE MANAGEMENT STRATEGY: AN EMPIRICAL STUDY OF IT-BUSINESS VALUE
}

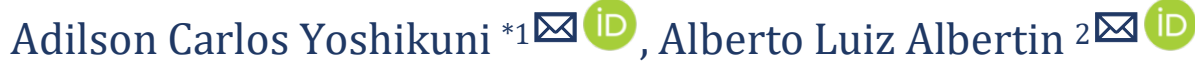 \\ *1, 2 Department Technology and Data Science, School of Business Administration of São Paulo at \\ Fundação Getulio Vargas (FGV-EAESP), Sao Paulo, Brazil
}

DOI: https://doi.org/10.29121/granthaalayah.v8.i10.2020.2088

Article Type: Research Article

Article Citation: Adilson Carlos Yoshikuni, and Alberto Luiz Albertin. (2020). LEVERAGING FIRM PERFORMANCE THROUGH INFORMATION TECHNOLOGY STRATEGIC ALIGNMENT AND KNOWLEDGE MANAGEMENT STRATEGY: AN EMPIRICAL STUDY OF IT-BUSINESS VALUE. International Journal of Research GRANTHAALAYAH, 8(10), 304-318. https://doi.org/10.29121/granthaa layah.v8.i10.2020.2088

Received Date: 16 October 2020

Accepted Date: 31 October 2020

\section{Keywords:}

Knowledge Management Strategy Information Technology (IT)

IT Strategic Alignment

IT-Business Value

IT Use Benefits

Business Process Performance Firm Performance

\section{ABSTRACT}

A central question for researchers and practitioners is whether and how knowledge management strategy (KMS) and information technology (IT) strategy alignment can help attain a competitive advantage. To address this question, this study draws on information strategic alignment (ITSA), and empirically examines the relationship between a firm's KMS and IT on competitive performance. The survey examined empirical data from 225 Brazilian companies using the partial least squares path modeling to test the hypotheses proposed herein. The findings demonstrated that KMS exert significant, positive effects on ITSA, benefits of IT use (BUTI), business process performance (BPP), and firm performance (FP). The results suggest that researchers and practitioners should look beyond the direct effects on FP, and identify how KMS and ITSA can be leveraged to enable and support BPP, and thereby contributed to knowledge management strategy and IT business value literature.

\section{INTRODUCTION}

For decades, strategic theory has provided organizations with competitive advantages (Grant, 2010; Wolf \& Floyd, 2017). Knowledge and information technology (IT) are the organization's most valuable and strategic resource and to remain competitive (Song, Li and Zhao, 2019; Nguyen, Ngo, Northey \& Siaw, 2019). 
Adilson Carlos Yoshikuni, and Alberto Luiz Albertin

In the last thirty years, many studies (e.g., Coltman, Tallon, Sharma, \& Queiroz, 2015; Gerow, Thatcher, \& Grover, 2015) have provided evidence to indicate that strategic alignment of IT generates business value for the firm and improves organizational performance (Queiroz, Tallon, Sharma, \& Coltman, 2018; Kim, Shin, Kim, \& Lee, 2011; Yoshikuni \& Albertin, 2017).

Knowledge management literature is rich with theoretical treatment linking the importance of knowledge application to enhance organizational performance measures (Andriani, Samadhi, Siswanto \& Suryadi, 2019; Jami Pour, Kouchak Zouchak \& Ahmad Zadeh, 2018; Nguyen et al., 2019; Zaim, Muhammed \& Tarim, 2019). However, there are few studies that empirically examine the relationship between knowledge management strategy (KMS) and IT (as knowledge application) on business process performance (BPP) and firm performance. According to Tallon, Queiroz, Coltman and Sharma (2019) IT-enabled business process agility and there persists the question, how can organizations reconcile the greater alignment between IT and business strategy to enhance BPP agility and FP? Additionally, past research has neglected to explore KMS causal relationships (Coltman et al., 2015; Gerow et al., 2015; Kohli \& Grover, 2008; Melville et al., 2004), making the current investigation of information technology strategic alignment (ITSA) and the outcomes performance more critical.

In doing so, this study extends the literature of knowledge management strategy and IT business value, thereby providing a better understanding about how IT assets create differential value (Aral \& Weill, 2007; Yoshikuni \& Albertin, 2017). Consequently, this study to address the literature gap explores the role of other mediator variables in the relationship between KM strategy and firm performance, as recommended by Song et al., (2019)

\section{THEORY AND HYPOTHESES DEVELOPMENT}

\subsection{KNOWLEDGE MANAGEMENT STRATEGY}

Knowledge management strategy (KMS) helps to organization to developed strategic models (Andriani et al., 2019; Bolisani \& Bratianu, 2017) that support them to link resources, technologies, process business and organizational forms to business strategy to translate the goal of making their organizations more intelligent into a strategic course of action (Song et al., 2019).

According to Martelo-Landroguez and Cepeda-Carrión (2016), these strategy processes are contemplated in process of knowledge creation, knowledge sharing, knowledge capture and knowledge application In an earlier study, Yoshikuni and Albertin (2014) argued that KMS is a collection of strategic processes involving, "participation", "communication", "comprehension" and "continuous learning".

Participation is the employees' engagement in actions and initiatives that reflect the organization's strategy and the development of corporate commitment to that strategy by knowledge creation (Jami Pour et al., 2018; Song et al., 2019). Thud, the knowledge sharing allows experiences and creating alternatives strategic routes (Bolisani \& Bratianu, 2017).

Knowledge sharing provides effective communication and allows an organization to disseminate its strategy to all employees (Bolisani \& Bratianu, 2017). Given this, communication clearly enabled by knowledge sharing and thus, knowledge creation occurs by employee collaboration (Caputo, Garcia-Perez, Cillo \& Giacosa, 2019, Kaplan \& Norton, 2000). Hence, the externalization knowledge process translates the strategy to all team members understand their contributions in the organization (Jami Pour et al., 2018; Zack, 1999).

Comprehension is the dissemination of the company's strategic direction such that all employees share the same goals, targets, company missions and values to create initiatives and action to active strategy objectives (Caputo el al., 2019; Zack, 1999). Therefore, the internalization knowledge capture process allows employees to develop routine to plan, execute and control strategy (Shujahat, Hussain, Javed, Malik, Thurasamy \& Ali, 2017).

Continuous learning organizations engage in processes through which they cultivate formal and informal skill (Nonaka et al. 2006). These processes tend to promote strategy culture systematization and the absorption of knowledge, skills, and attitude (Nonaka \& Toyama 2005; Shujahat et al., 2017) to create the "combination" knowledge strategy (Bolisani \& Bratianu, 2017).

Therefore, these factors of KMSs direct corporations towards objectives that provide them with long-term competitive advantages (Bolisani \& Bratianu, 2017; Nonaka et al., 2006; Jami Pour et al., 2018; Yoshikuni \& Albertin, 2014; Zack, 1999). In this way, KMSs promote broad strategic process that drive intention to use resources and technology in the business processes (Al-Ammary, 2014; Shujahat et al., 2017; Zaim et al., 2019) and generating 
Leveraging Firm Performance Through Information Technology Strategic Alignment and Knowledge Management Strategy: An Empirical Study of It-Business Value

performance outcomes. The KMS created, captured, and shared between businesses is a key predictor of IT strategic alignment (Tallon et al., 2019, Melville et al., 2004) and corporate performance (Al-Ammary, 2014; Shujahat et al., 2017; Song et al., 2019).

Given the above, we predict that KMS is antecedent of ITSA, BUTI, BPP and FP:

H1: Knowledge management strategy is positively associated with IT strategic alignment.

H2: Knowledge management strategy is positively associated with the benefits of IT use.

H3: Knowledge management strategy is positively associated with business process performance.

H4: Knowledge management strategy is positively associated with firm performance.

\subsection{INFORMATION TECHNOLOGY STRATEGIC ALIGNMENT}

Researchers have studied ITSA extensively in the last thirty years (Coltman et al., 2015; Gerow et al., 2015). More specifically, researchers have explored how the alignment of IT-related processes generates business value for a firm (Kim et al., 2011; Tallon et al., 2019). Generally, IT alignment and business processes occur in a continuously adjusting synergistic relationship, integrating business strategy and IT assets (Queiroz, Tallon, Sharma \& Coltman, 2018; Li \& Chan, 2019).

Previous studies on IT-asset portfolios (Xue, Ray \& Sambamurthy, 2012; Yoshikuni \& Albertin, 2017) claim that IT-asset portfolios can facilitate strategic alignment in four ways: infrastructural, transactional, informational, and strategic. According to Aral \& Weill (2007) the IT infrastructural component represents the base foundation of shared IT services in multiple contexts in the organization (e.g., serves, networks, laptops, and databases). The IT transactional component relates to how IT assets can automate business-related routine processes (e.g., accounting, shop floor control, purchasing, sales) broad all organization. IT informational application of IT assets refers to those processes that provide information that make it easier to carry out multiple business processes (e.g., decision support systems, business intelligence).

Finally, the use of IT for strategic ends helps a firm to gain advantages in a competitive marketplace (e.g., enterprise performance management). ITSA offers a more "holistic view" (Gerow et al., 2015; Li \& Chan, 2019) of alignment by simultaneously considering a business' strategies, IT resources, and processes (Chen et al., 2010; Henderson \& Venkatraman, 1999; Li \& Chan, 2019). ITSA occurs when IT resources are coordinated, complementary (Mikalef \& Pateli, 2017; Yayla \& Hu, 2012), integrated (Li \& Chan, 2019), part of business processes (Tallon et al., 2019; Queiroz et al., 2018) and IT application portfolios (Coltman et al., 2015; Tallon \& Pinsonneault, 2011). By incorporating IT resources into business strategies in this manner, firms can be more efficient and realize innovative benefits they may have otherwise missed out on (Tallon, 2008; Xue et al., 2012). So, this alignment creates value for the firm, thereby improving outcomes performance (Melville et al., 2004; Mikalef \& Pateli, 2017).

Therefore, we offer the following hypothesis:

H5: IT strategic alignment is positively associated with benefits of IT use.

\subsection{THE BENEFITS OF IT USE}

A company's capacity to reap the benefits of IT use (BUTI) influences that company's ability to engage in competitive actions (Kohli \& Grove, 2008; Li \& Chan, 2019; Tallon, Queiroz, Coltman, \& Sharma, 2019), respond to changes in the business environment, develop entrepreneurial activities, and enable co-evolutionary processes (Albertin \& Albertin, 2012; Melville et al., 2004;Yoshikuni \& Albertin, 2017).

According to Taher (2012), the BUTI are evident along operational, tactical, and strategic dimensions. Moreover, these benefits can be financial, non-financial, or intangible in nature, but can nonetheless provide value to the organization and affect firm performance (Melville et al., 2004; Yoshikuni and Albertin, 2017).

The operational benefits of using IT are couched in IT's capacity to automate company activities (Li \& Chan, 2019; Tallon et al., 2019). As IT assets infrastructure that enables the connection between companies, shares information and data structure, and deployment of the IT value across the enterprise (Aral \& Weill, 2007; Yoshikuni \& Albertin, 2017). 
According to Davenport and Harris (2007), and Davenport, Harris, and Morison (2010), the tactical and strategic dimensions of IT use can be combined to facilitate specific types of analysis. IT can be used to gather data and systemic knowledge that support organizational decision making and plan for future business endeavors (Aydiner et al., 2019b; Mikalef et al., 2019; Tallon et al., 2019). These analyses (and the foresight they provide) inform strategic processes, allowing firms to diagnose, plan, formulate, and implement business strategies in a flexible manner. This allows the organization to adapt to changing business environments as needed (Arnott \& Pervan, 2014; Yoshikuni and Albertin, 2018)

In summary, IT use can reduce spending, improve productivity, and increase organizational flexibility (Li \& Chan, 2019; Tallon, Queiroz, Coltman, \& Sharma, 2016; Yoshikuni \& Albertin, 2017). A combination of the tactical and strategic applications of IT demonstrates that the use of IT can also provide analytical benefits. These benefits relate to the quality of the information that organizations use to make decisions. As a result, the analytical benefits of IT use can improve organizational efficiency, promote innovation (Chatterjee, Moody, Lowry, Chakraborty and Hardin (2020), and increase revenue (Aral \& Weill, 2007; Davenport et al, 2010; Davenport \& Harris, 2007; Tallon et al., 2016, 2019; Xue et al., 2012). Clearly, a firm's use of IT influences the business processes in which it engages (Tallon, 2008), and consequently creates value for that firm (Chatterjee et al., 2020; Kohli \& Grover, 2008; Melville et al., 2004; Tallon et al., 2016; Tallon et al., 2019).

So, we propose the following hypothesis:

H6: The IT use is positively associated with business process performance.

Firm performance

Business processes help organizations to realize salient objectives (Kaplan \& Norton, 2000; Porter, 1996). Taken together, the realization of organizational goals can be described as corporate performance (Melville et al., 2004; Tallon et al., 2019; Tallon \& Pinsonneault, 2011). Process-level performance denotes a range of measures associated with enhancing the operational efficiency of specific business processes. Some of these metrics include securing customers, transforming products, and/or delivering those products or services to customers (Kaplan \& Norton, 2000).

Business process performance (BPP) manifests through activities that transform inputs to outputs (Melville et al., 2004; Tallon et al., 2016, 2019). These activities relate to innovation, operations, and post-sale support (Kaplan \& Norton, 2000). Moreover, analytical activities which support organizational decision making (Adydiner et al., 2019; Davenport et al., 2010) are similarly part of business processes, and therefore influence firm performance (Grant, 2010; Kaplan \& Norton, 2000). Given the importance of business processes, their quality is a critical predictor of a firm's ability to deliver products and services efficiently (Mikalef \& Pateli, 2017; Tarhan, Turetken, \& Reijers, 2015). Thus, we predict that business process performance affects a firm's overall performance:

H7: Business process performance is positively associated with firm performance.

Models of corporate performance use different metrics (i.e., financial, and non-financial) to gauge various outcomes associated with a firm's capacity to achieve organizational objectives (Kaplan \& Norton, 2000; Tallon et al., 2019; Yoshikuni \& Albertin, 2017). Financial measurements of corporate performance typically evaluate a firm's long-term value, which typically results from the effectiveness with which a firm produces and sells its goods and realizes its strategies (Kaplan and Norton, 2000). Achieving long-term value for shareholders is necessary to understand the needs and conditions that create value for clients. "Customer performance" is a non-financial measure of organizational performance (Yoshikuni \& Albertin, 2017) that relates to the attributes of the goods and services a company provides, the relationships that a company cultivates with customers, and the image of the company's brand (Kaplan \& Norton, 2000).

This literature review has presented important concepts related to knowledge management strategy, information strategic alignment, the benefits of IT use, and firm performance. In this study, we adopt a processoriented perspective to propose a theoretical model of IT-business value as recommended by Melville et al., (2004), see Figure 1. 


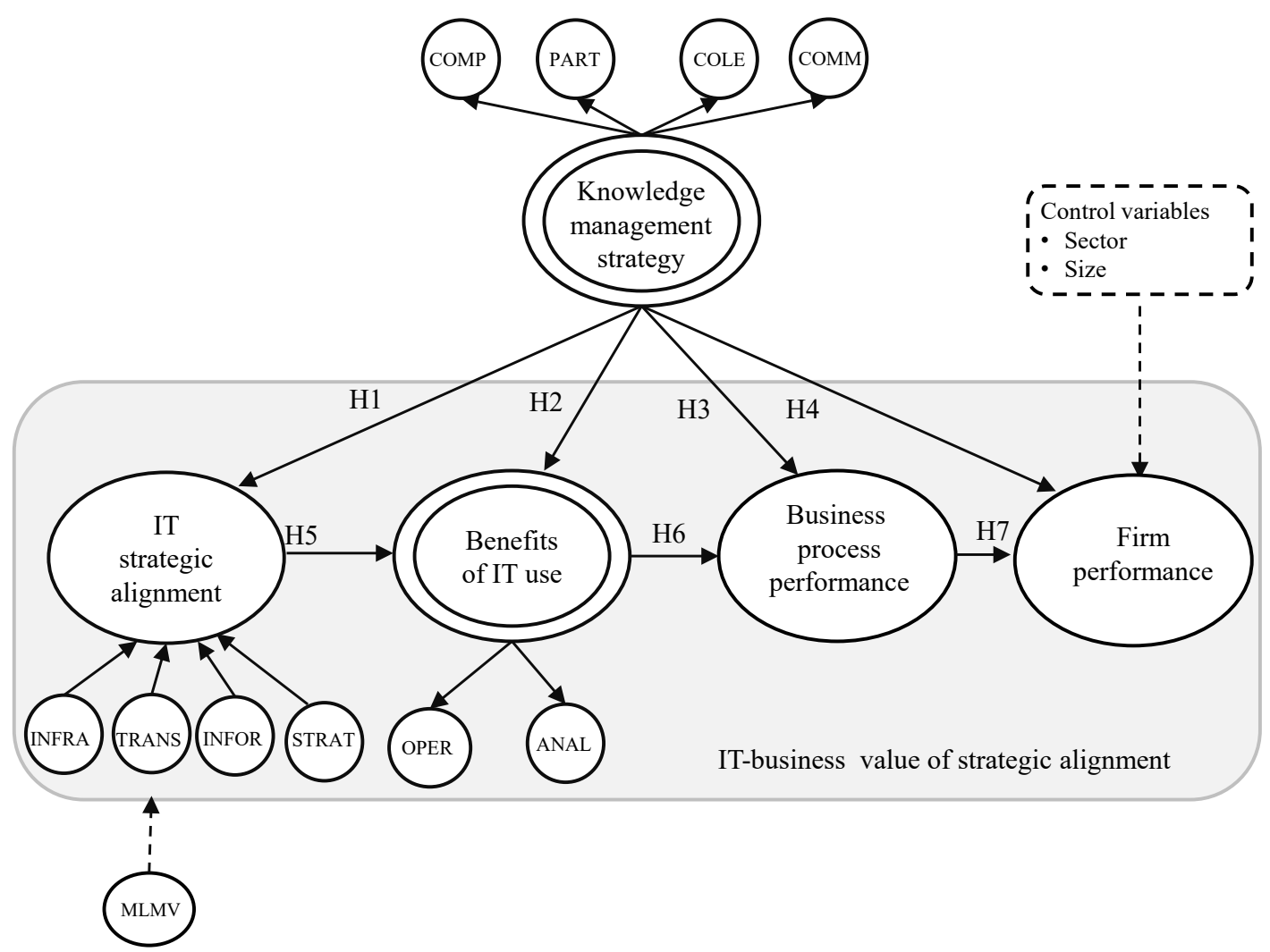

Figure 1: Proposal Model

Notes: In this model, the latent variables include knowledge management strategy (KMS), information technology strategic alignment (ITSA), benefits of IT use (BUTI), business process performance (BPP), and firm performance (FP). Second-order reflexive constructs associated with KMS are comprehension (COMP), participation (PART), communication (COMM), and continuous learning (COLE). Items that comprise the ITSA construct are infrastructure (INFRA), transactional (TRANS), informational (INFOR), and strategic (STRAT). Second-order reflexive constructs associated with BUTI are operational (OPER) and analytical (ANAL) dimension. Control variables was related to the business sector (SE) and numbers of employees (Size). Where possible, this model also controls for common method bias through Chin, Thatcher, Wright, and Steel's (2013) measured marker variable technique (MLMV). To facilitate model visualization, we omit indicators for the constructs.

\section{METHODOLOGY}

\subsection{SAMPLE}

The target population was a collection of organizations couched in several business sectors, and the respondents in this study include CEOs, VPs, directors, managers, supervisors, coordinators, and business executives involved in their respective company's management. Respondents had between 8 and 30 years of experience in executive management and possessed substantial knowledge of the constructs in the context of their companies. All items were evaluated using a five-point Likert-type scale ranging from 1 (strongly disagree) to 5 (strongly agree), representing an interval scale for measuring respondents' perceptions.

\subsection{PRETEST}

The pretest was positive and provided evidence for the quality of the questionnaire. It was administered to personnel in 23 organizations, we exceeded the recommended sample size of 15 (Malhotra, 2006). The participants provided feedback on the questionnaire which was incorporated into its final form. See Appendix A. 


\subsection{DATA TREATMENT}

Thirty-five questionnaires were returned with missing data and the final sample size $(\mathrm{N}=225)$ satisfies the requirement for partial least squares path modeling (PLS-PM; Henseler, Ringle, \& Sinkovics, 2009). The literature on PLS-PM mandates that a sample be no less than 10 times the number of structural paths that predict a given reflective construct (Hair, Hult, Ringle, and Sarstedt (2013), and 225 cases is sufficiently large to produce consistent results in the test of our model.

We used the Mahalanobis distance metric $\left(\mathrm{dM}^{2}\right.$; Marôco, 2010) to identify outliers in our data, and three cases were removed from subsequent analyses.

\subsection{STATISTICAL TECHNIQUE}

We used PLS-PM because is considered appropriate for this study, it allows the simultaneous estimation of multiple causal relationships between one or more exogenous variables and one or more endogenous (Hair et al., 2013). We performed all PLS-PM analyses with the SmartPLS 2.0 M3 program (Ringle, Wende, \& Will, 2005).

Analysis of the sample showed $10 \%$ to consist of C-levels personnel, $72 \%$ to consist of management and coordination personnel, and $24 \%$ to consist of supervisors with the power to make decisions in their respective companies.

Table 1 summarize the makeup of the sample in terms of the sector in which they operate, the number of workers they employ.

Table 1: Demographic profile of the sample ( $\mathrm{N}=222$ organizations)

\begin{tabular}{|c|c|c|c|}
\hline Sector & & No. employees & \\
\hline Agro-business & $2 \%$ & $\leq 9$ & $2 \%$ \\
\hline Commerce & $6 \%$ & $10-49$ & $5 \%$ \\
\hline Finance & $14 \%$ & $50-99$ & $16 \%$ \\
\hline Manufacturing & $31 \%$ & $100-249$ & $14 \%$ \\
\hline Service & $42 \%$ & $250-499$ & $5 \%$ \\
\hline Government & $5 \%$ & $\geq 500$ & $58 \%$ \\
\hline
\end{tabular}

The sample was largely characterized by firms in the services, manufacturing, and finance sectors (87\% of companies surveyed). Similarly, organizations with over 500 employees (58\%) were more heavily represented in our sample than firms of other sizes.

\section{RESULTS}

\subsection{REFLECTIVE CONSTRUCT}

We started analyzing the outer loadings relevance testing according (Hair et al., 2013) in the crossed loads to check the discriminant validity of the model and the outer loading were $<0.40$. The convergent validity was evaluated and the square root of the strategy indicator's AVE. Table 2 shows that all AVE and internal consistency (should be higher than 0.70) were acceptable. Most indicators' outer loadings were than 0.70. Moreover, we considered indicators with outer loadings between 0.40 and 0.70 , because of increases in AVE and composite reliability above the threshold values suggested by Hair et al. (2013). The indicators have higher factor loadings on their assigned constructs and lower factor loadings on other constructs, thereby indicating discriminant validity (Chin, 1998; Ringle et al., 2014), see Appendix A.

Table 2: Pearson correlations and descriptive statistics for latent variables

\begin{tabular}{l|c|c|c|c|c|c|c|c|c}
\hline Latent variables & 1 & 2 & 3 & 4 & 5 & 6 & 7 & 8 & 9 \\
\hline 1 - Communication & 0.70 & & & & & & & & \\
2 - Comprehension & 0.68 & 0.79 & & & & & & & \\
3 - Continuous Learning & 0.60 & 0.71 & 0.73 & & & & & & \\
\hline
\end{tabular}


Leveraging Firm Performance Through Information Technology Strategic Alignment and Knowledge Management Strategy: An Empirical Study of It-Business Value

\begin{tabular}{l|c|c|c|c|c|c|c|c|c}
\hline 4 - Participation & 0.63 & 0.72 & 0.66 & 0.71 & & & & & \\
5 - ITSA & 0.49 & 0.55 & 0.53 & 0.44 & $\#$ & & & & \\
6 - Analytical & 0.52 & 0.55 & 0.56 & 0.52 & 0.83 & 0.82 & & & \\
7 - Operational & 0.39 & 0.41 & 0.42 & 0.33 & 0.74 & 0.73 & 0.76 & & \\
8 - Business Process Performance & 0.51 & 0.54 & 0.57 & 0.44 & 0.55 & 0.56 & 0.44 & 0.76 & \\
9 - Firm Performance & 0.42 & 0.42 & 0.49 & 0.38 & 0.46 & 0.43 & 0.34 & 0.70 & 0.72 \\
\hline AVE & 0.49 & 0.63 & 0.54 & 0.51 & $\#$ & 0.68 & 0.58 & 0.58 & 0.52 \\
Composite Reliability & 0.80 & 0.87 & 0.82 & 0.81 & $\#$ & 0.93 & 0.84 & 0.81 & 0.86 \\
Mean & 3.26 & 3.16 & 3.10 & 3.23 & 3.11 & 3.07 & 3.17 & 3.46 & 3.53 \\
Standard Deviation & 0.70 & 0.85 & 0.80 & 0.82 & 0.93 & 0.83 & 0.71 & 0.73 & 0.73 \\
Variance Coefficient & 0.21 & 0.27 & 0.26 & 0.25 & 0.30 & 0.27 & 0.22 & 0.21 & 0.21 \\
Skewness & 0.18 & 0.08 & 0.01 & 0.11 & 0.03 & 0.02 & 0.01 & 0.18 & 0.31 \\
Kurtosis & 0.05 & 0.72 & 0.51 & 0.76 & 0.38 & 0.24 & 0.17 & 0.33 & 0.10 \\
\hline
\end{tabular}

Note: The symbol \# indicates the ITSA formative measurement

The second-order KMS and BUTI variables respectively demonstrated AVE values of 0.61 and 0.72 . Both the second-order KMS and BUTI variables had CR estimates of 0.90 . We compared the Fornell-Larcker criterion to the square root of KMS's (0.78) and BUTI (0.85) AVE values that satisfied the criterion.

\subsection{FORMATIVE CONSTRUCT}

We analyzed the asses the formative construct's convergent validity by examine global single item (ITSA_G) to test the redundancy analysis and correlation between the construct ITSA and ITSA_G was 0.881 higher than 0.80 that satisfied the test of redundancy analysis according Hair et al., (2013), see Table 3.

We checked the collinearity of indicators and the variance inflation factor (VIF) were lower than 5 and each indicator's tolerance (VIF) were higher than 0.20 and the VIF results are satisfactory, no critical level of collinearity (Hair et al., 2013). Table 3 shows the outer weights and significance tests for all indicators ( $<$ 0.01) (Hair et al., 2013).

Table 3: Outer weight significance testing results for ITSA

\begin{tabular}{ccccccc}
\hline Formative indicators & Outer weights & Mean & Standard Deviation & Standard Error & $t$ value & $p$ \\
value
\end{tabular}

\subsection{STRUCTURAL MODEL}

We also applied Chin et al.'s (2013) measured marker variable technique (MLMV) to control for common method bias and used four items designed to have the least possible logical correlation with other constructs under investigation. Results of the MLMV analysis showed that no differences in the value of R square, suggesting that common method bias was unlikely to be a significant concern for this study.

We evaluated the respective influences of all control variables on the model's endogenous variables and sector and size demonstrated no statistical significance ( $p>0.05)$.

Figure 2 shows the adjusted model with non-significant MLMV removed. All numerals next to the paths represent structural path coefficients. 


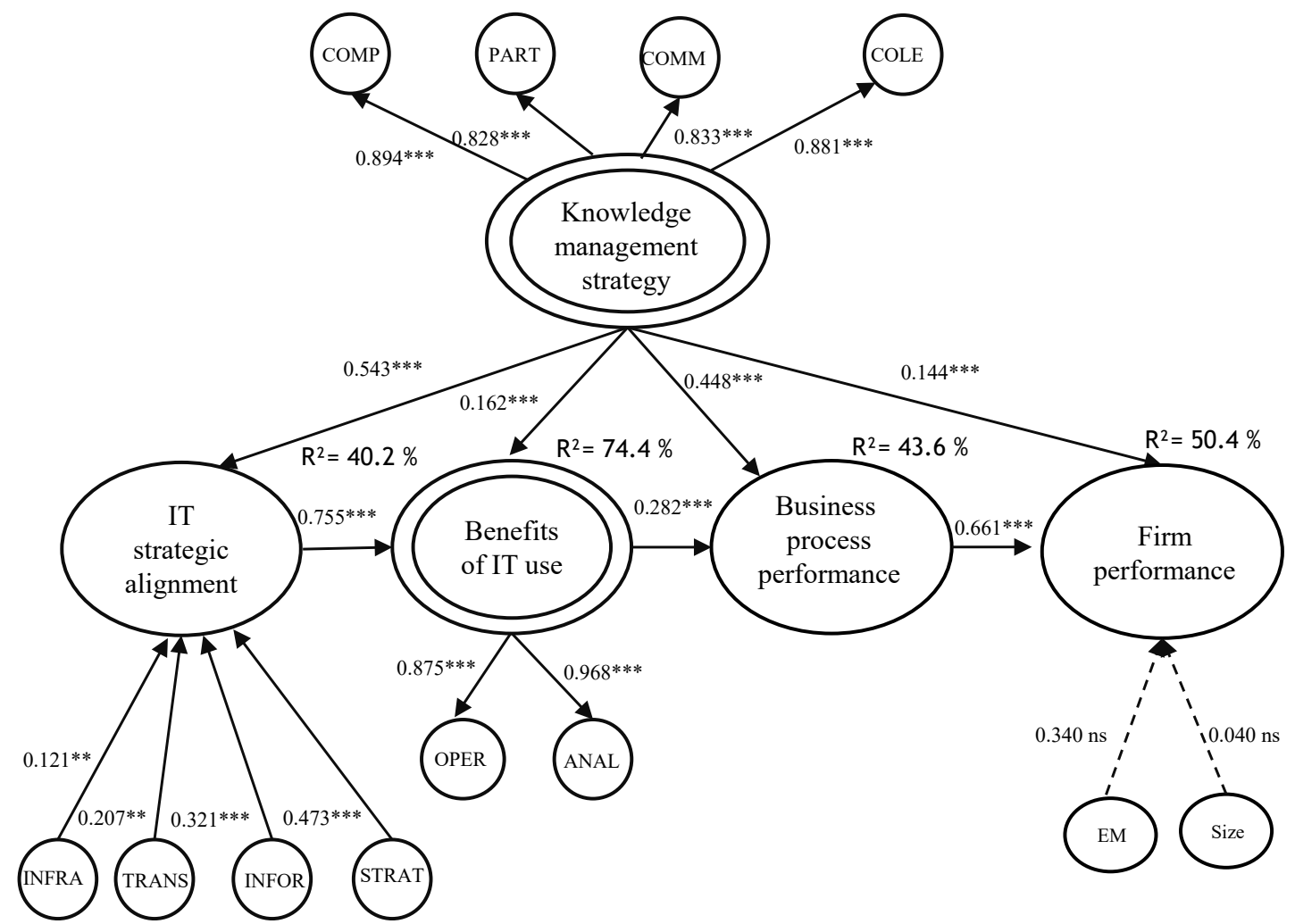

Figure 2: Structural Model

Notes: Significance testing was performed using the bootstrap method ( $N=222$ with 5,000 replications). Indicators for all constructs were omitted from the figure for the sake of simplicity. ${ }^{*} p<0.05 ;{ }^{* *} p<0.01 ;{ }^{* * *} p<0.001$ ns no-significance $(\mathrm{p}>0.05)$.

\subsection{THE MEDIATING EFFECT OF INFORMATION TECHNOLOGY STRATEGIC ALIGNMENT}

To begin the mediation analysis, we estimated the relationship between KMS and BUTI without including ITSA as a possible mediator. We also estimated the association between KMS and FP without including BPP as a mediator.

The value of variance accounted for (VAF) indicates the size of the indirect effect in relation to the total effect (Hair et al., 2013). According to Hair et al. (2013), when the VAF is less than 20\%, (almost) no mediation takes place. In contrast, when the VAF is greater than $80 \%$, one can assume a full mediation. When the VAF is between $20 \%$ and $80 \%$, then partial mediation is the likely result. The presence of significant indirect effects led us to conclude that ITSA likely mediates the relationship between KMS and BUTI (VAF $=72 \%$ ), and BPP mediates the relationship between KMS and FP (VAF = 66\%). The low VAF for the relationship between KMS and BPP (as mediated by BUTI) suggests that there is no mediation in this relationship. See Table 4 for details of these mediation analyses.

Table 4: Results of variance accounted for (VAF)

\begin{tabular}{|c|c|c|c|c|c|c|c|}
\hline $\begin{array}{c}\text { Relationships between latent } \\
\text { variables }\end{array}$ & $\begin{array}{c}\text { Indirect } \\
\text { effect }\end{array}$ & $\begin{array}{c}\text { Standard } \\
\text { error }\end{array}$ & $\begin{array}{c}t \\
\text { value }\end{array}$ & $\begin{array}{c}p \\
\text { value }\end{array}$ & $\begin{array}{l}\text { Direct } \\
\text { effect }\end{array}$ & $\begin{array}{l}\text { Total } \\
\text { effect }\end{array}$ & VAF \\
\hline OKS $\rightarrow$ ITSA $\rightarrow$ BUTI & 0.410 & 0.064 & 6.449 & 0.000 & 0.163 & 0.573 & $72 \%$ \\
\hline $\mathrm{OKS} \rightarrow \mathrm{BUTI} \rightarrow \mathrm{BPP}$ & 0.046 & 0.020 & 2.285 & 0.023 & 0.448 & 0.494 & $9 \%$ \\
\hline $\mathrm{OKS} \rightarrow \mathrm{BPP} \rightarrow \mathrm{FP}$ & 0.274 & 0.105 & 2.616 & 0.010 & 0.144 & 0.418 & $66 \%$ \\
\hline
\end{tabular}

\subsection{HYPOTHESIS TESTS}

All hypotheses outlined in Figure 1 were supported $(\mathrm{p}<0.05)$. See Table 5 for the details of those predictions. 
Leveraging Firm Performance Through Information Technology Strategic Alignment and Knowledge Management Strategy: An Empirical Study of It-Business Value

Table 5: Hypotheses and results

Hypotheses

Results

H1 Knowledge management strategy is positively associated with IT strategic alignment.

Supported

H2 Knowledge management strategy is positively associated with the benefits of IT use.

Supported

H3 Knowledge management strategy is positively associated with business process performance Supported

H4 Knowledge management strategy is positively associated with firm performance

H5 IT strategic alignment is positively associated with benefits of IT use.

H6 The IT use are positively associated with business process performance

Supported

H7 Business process performance is positively associated with firm performance.

Supported

Supported

Supported

\section{DISCUSSION AND CONCLUSIONS}

In this study, we empirically examined a model with which we evaluated the business value of aligning IT with strategic activities. Specifically, we looked at antecedents (KMS and ITSA) and outcomes (BPP and FP) associated with the benefits of IT use in organizational settings. The study appears to be an excellent option for directing the adoption of strategy-oriented technology in business processes, because it helps to identify the benefits of IT use and how those benefits influence firm performance, and extends the knowledge of the literature of knowledge management strategy and information technology strategic alignment.

It has demonstrated that knowledge management strategy provides activities to create, share, capture and application strategic information concerning how a firm can leverage its capabilities and use its resources to enhance outcomes performance, and contribute to fill knowledge gaps mentioned in recent study (Song et al., 2019). Furthermore, it was showed that it is necessary to involve employees in the successful implementation of corporate. In this vein, we demonstrated knowledge creation, sharing and capture between businesses is the key predictor of business value associated with the strategic alignment of IT, in line with previous studies (Al-Ammary, 2014; Shujahat et al., 2017).

This analyses further demonstrated that the adoption of IT was associated with processes that provide useful intelligence to an organization. This intelligence can help an organization to become more efficient, effective, or innovative. Hence, this study contributed to respond to the question mentioned by Tallon et al., 2019, and demonstrated how KMS reconciles the greater IT strategic alignment to enhance BPP agility and FP.

It was also showed that the benefits of IT use in the analytical domains assist managers in their decision making. We believe that executives have greater autonomy to make decisions related to productivity, and largely increase revenues through the generation of new products and services. This assumption is consistent with the notion that applications of IT are consolidated in Brazilian companies, in line with previous studies of decision support systems (Aydiner et al., 2019b; Davenport et al., 2010).

\section{IMPLICATIONS FOR ORGANIZATIONS AND RESEARCHERS}

In addition to the theoretical contributions they provide, our research findings also produce a significant amount of insight in terms of practical, managerial knowledge.

First, the result demonstrated that KMS is a key resource to enable ITSA to enhance outcomes performance.

Second, the findings show that ITSA investment is significantly and positively related to BUTI.

This result demonstrates the importance of IT use to perform activities related to the value chain and support decision making related to future strategic plans. This result helps us to understand the role that business processes plays in the value chain.

Arguably, one of the greatest contributions this research is a more comprehensive understanding of the antecedents and outcomes associated with the benefits of IT use. Specifically, we showed that the benefits of IT use generate added business value when IT is strategically aligned with several business activities. This alignment provides integration and harmonization between infrastructural, transactional, informational, and strategic IT assets. This finding is reiterated by the fact that ITSA exerted a strong effect $(0.755)$ on the benefits of IT use, as well as the high level of variance explained (74.4\%). Taken together, these results provide evidence for the importance of aligning an organization's IT use with its activities. 
Third, and consistent with past research in this domain (see Grant, 2010; 2012; Melville et al., 2004, Tallon, 2008; Tarhan et al., 2015), we found BPP to be significantly and positively associated with FP.

Finally, this study showed the utility of VAF to illustrate the mediating roles played by ITSA, BPP, and BUTI. The relationship between KMS and BUTI were partially mediated by ITSA. Similarly, the relationship between KMS and FP was partially mediated by BPP. Taken together, these mediator analyses help to show how business processes affect firm performance. In contrast to the mediated relationships described above, the relationship between KMS and BPP was not mediated by BUTI.

Ultimately, the results of this study show how organizations can leverage the strategic alignment of IT to create business value through the dissemination of knowledge management strategy. As such, this study can help organizations achieve greater efficiency and effectiveness in their implementation of IT to realize their strategies. As a result of this increased efficiency and effectiveness, they can achieve greater firm performance. Therefore, the current study justifies the adoption of IT alignment as appropriate and rational, even with limited resources available to facilitate such an adoption and contribute to IT-business value and strategy management literature.

\section{STUDY LIMITATIONS}

Although the study provided significant insight into the use of IT, it is important to acknowledge the study's limitations as well. However, future research could investigate the longitudinal design to an in-depth analysis of the mechanism that KM strategy acts on outcomes performance. Other future research could investigate this proposal model in other contexts. Additionally, a future study could consider the moderating influence of environmental turbulence, such as higher-level technological, dynamism, and heterogeneity, to provide insights into the practice of knowledge management strategy and information technology enhance outcomes performance.

\section{APPENDIX A}

Abbreviated questionnaire

All items were presented in the firm of five-point Likert-type scales ranging from 1 (strongly agree) to 5 (strongly disagree).

Organizational knowledge of strategy

Employees participate in...

- (PART_1) teams that affect how company strategic objectives are attained.

- (PART_2) the generation of solutions to achieve common goals.

- (PART_3) teams to develop actions that promote effective results.

- (PART_4) various levels of decision making to analyze, plan, and implement actions and strategic initiatives.

The company engages in strategic communication...

- (COMM_1) through collaborative meetings and discussions on strategic objectives.

- $\quad$ (COMM_2) through systematic strategic guidelines disseminated among employees.

- (COMM_3) through continuous and open collaboration.

- (COMM_4) that informs what is expected of each employee in relation to established objectives.

Employees comprehend...

- $\quad$ (COMP_1) the main goal (common vision) to be achieved in the medium and long term.

- $\quad$ (COMP_2) senior management's prioritization of objectives and targets.

- (COMP_3) the organization's mission.

- (COMP_4) the organization's philosophy and corporate belief system.

The company promotes continuous learning...

- (COLE_1) through systematic processes that analyze organizational successes and failures.

- (COLE_2) to employees rethink the old and creating the new.

- (COLE_3) by developing skills needed to create ideas that solve old problems and create new paradigms.

International Journal of Research -GRANTHAALAYAH 
Leveraging Firm Performance Through Information Technology Strategic Alignment and Knowledge Management Strategy: An Empirical Study of It-Business Value

- (COLE_4) by analyzing stakeholder demands and rethinking, improving, and restructuring the company.

Strategic Alignment of Information Technology

- (ITSA_1) The base foundation of IT infrastructure is aligned with the business' strategy to share IT services across multiple applications.

- (ITSA_2) The IT transactions application portfolio is aligned with the business' strategy to execute business processes associated with the value chain.

- (ITSA_3) The IT informational application portfolio is aligned with the business' strategy to provide information needed to optimize business processes.

- (ITSA_4) The IT strategic application portfolio is aligned with the business' strategy to gain competitive advantages and achieve business goals.

- $\quad$ (ITSA_G) The IT assets portfolio is aligned with the business' strategy.

Benefits of IT use

The use of IT creates operational benefits...

- (OPER_1) to execute operational activities geared towards achieving targets and business goals through broad IT infrastructure.

- (OPER_2) to generate high-scale, mobile access to business information through public IT infrastructure.

- (OPER_3) to enable the firm to reconfigure and adapt to new environmental requirements through broad IT infrastructure.

- (OPER_4) to enable the firm to integrate and share data, information, and knowledge across different business process and sites.

- (OPER_5) to execute and support of operational activities in the value chain.

- OPER_6) to reduce operational costs associated with the support and execution of operational activities in the value chain.

- OPER_7) to improve the quality of products and services.

- (OPER_8) to optimize operation capacity.

The use of IT creates analytical benefits...

- (TACT_2) to improve the management of planning, execution, and control.

- (TACT_3) to improve the efficiency and effectiveness of operational activities in the value chain.

- (TACT_4) to improve management's analytical capabilities, allowing for better decision making.

- (STRAT_2) to develop competitive advantages.

- (STRAT_3) to satisfy customers' needs.

- $\quad$ (STRAT_4) to support strategy management

Business process performance as measured by activities on the value chain is efficient and effective means of promoting...

- $\quad($ BP_1) business process innovation to create new products and services.

- (BP_2) business process operations.to transforming and delivering products and services

- (BP_3) business process post-sale to create loyal customers

Firm Performance:

- (FP_1) The company reaches its goals for profitability to satisfied shareholders

- (FP_2) The business is efficient in terms of spending (cost management, expenses and investments) to meets goals for productivity.

- (FP_3) The company reaches its goals with respect to revenues.

- (FP_4) Customers are satisfied with the value delivered by the company.

- (FP_5) Customers remain loyal to the company. 
- (FP_6) The market recognizes the company's image (brand) for the quality of the services and/or products it represents.

\section{APPENDIX B}

Cross-loadings of variables.

\begin{tabular}{|c|c|c|c|c|c|c|c|c|c|c|}
\hline First Latent Variable & Items & 1 & 2 & 3 & 4 & 5 & 6 & 7 & 8 & $p$ \\
\hline \multirow[t]{4}{*}{$1-$ COLE } & COLE_1 & 0.601 & 0.382 & 0.379 & 0.364 & 0.205 & 0.277 & 0.294 & 0.210 & 0.000 \\
\hline & COLE_2 & 0.731 & .487 & 0.574 & 0.506 & 0.269 & 0.360 & 0.380 & 0.276 & 0.000 \\
\hline & COLE_3 & 0.802 & .444 & 0.569 & 0.575 & 0.340 & 0.497 & 0.438 & 0.386 & 0.000 \\
\hline & COLE_4 & 0.783 & 0.460 & 0.545 & 0.484 & 0.394 & 0.477 & 0.535 & 0.519 & 0.000 \\
\hline \multirow[t]{4}{*}{$2-\mathrm{COMM}$} & COMM_1 & 0.443 & 0.706 & 0.518 & 0.492 & 0.279 & 0.432 & 0.381 & 0.330 & 0.000 \\
\hline & COMM_2 & 0.350 & 0.661 & 0.372 & 0.352 & 0.207 & 0.244 & 0.295 & 0.284 & 0.000 \\
\hline & COMM_3 & 0.388 & 0.686 & 0.350 & 0.362 & 0.251 & 0.280 & 0.331 & 0.290 & 0.000 \\
\hline & COMM_4 & 0.493 & 0.753 & 0.624 & 0.523 & 0.348 & 0.462 & 0.399 & 0.271 & 0.000 \\
\hline \multirow[t]{4}{*}{3 - СОМР } & COMP_1 & 0.530 & 0.569 & 0.803 & 0.603 & 0.309 & 0.469 & 0.394 & 0.279 & 0.000 \\
\hline & COMP_2 & 0.517 & 0.567 & 0.803 & 0.567 & 0.330 & 0.370 & 0.426 & 0.381 & 0.000 \\
\hline & COMP_3 & 0.560 & 0.513 & 0.757 & 0.524 & 0.247 & 0.383 & 0.411 & 0.326 & 0.000 \\
\hline & COMP_4 & 0.641 & .510 & 0.800 & 0.571 & 0.399 & 0.501 & 0.479 & 0.358 & 0.000 \\
\hline \multirow[t]{4}{*}{4 - PART } & PART_1 & 0.422 & 0.477 & 0.594 & 0.765 & 0.218 & 0.363 & 0.226 & 0.182 & 0.000 \\
\hline & PART_2 & 0.500 & 0.416 & 0.476 & 0.702 & 0.207 & 0.365 & 0.338 & 0.272 & 0.000 \\
\hline & PART_3 & 0.428 & 0.476 & 0.476 & 0.710 & 0.237 & 0.338 & 0.337 & 0.285 & 0.000 \\
\hline & PART_4 & 0.541 & 0.423 & 0.498 & 0.677 & 0.277 & 0.407 & 0.344 & 0.336 & 0.000 \\
\hline \multirow[t]{4}{*}{5 - OPER } & OPER_1 & 0.357 & 0.313 & 0.299 & 0.225 & 0.835 & 0.540 & 0.362 & 0.280 & 0.000 \\
\hline & OPER_3 & 0.104 & 0.143 & 0.149 & 0.112 & 0.488 & 0.342 & 0.171 & 0.159 & 0.000 \\
\hline & OPER_5 & 0.315 & 0.248 & 0.345 & 0.260 & 0.836 & 0.588 & 0.363 & 0.235 & 0.000 \\
\hline & OPER_6 & 0.429 & 0.439 & 0.398 & 0.357 & 0.824 & 0.683 & 0.400 & 0.338 & 0.000 \\
\hline \multirow[t]{6}{*}{6 - ANAL } & STRA_2 & 0.466 & 0.380 & 0.441 & 0.412 & 0.641 & 0.865 & 0.472 & 0.337 & 0.000 \\
\hline & STRA_3 & 0.525 & 0.446 & 0.487 & 0.432 & 0.596 & 0.849 & 0.464 & 0.412 & 0.000 \\
\hline & STRA_4 & 0.469 & 0.457 & 0.445 & 0.427 & 0.576 & 0.811 & 0.465 & 0.365 & 0.000 \\
\hline & TACT_2 & 0.451 & 0.480 & 0.453 & 0.444 & 0.654 & 0.808 & 0.461 & 0.332 & 0.000 \\
\hline & TACT_3 & 0.408 & 0.345 & 0.401 & 0.373 & 0.545 & 0.752 & 0.416 & 0.298 & 0.000 \\
\hline & TACT_4 & 0.446 & 0.461 & 0.468 & 0.464 & 0.573 & 0.848 & 0.509 & 0.354 & 0.000 \\
\hline \multirow[t]{3}{*}{7 - BPP } & BPP_1 & 0.395 & 0.420 & 0.445 & 0.316 & 0.365 & 0.428 & 0.739 & 0.509 & 0.000 \\
\hline & BPP_2 & 0.434 & 0.370 & 0.422 & 0.350 & 0.313 & 0.345 & 0.785 & 0.559 & 0.000 \\
\hline & BPP_3 & 0.474 & 0.367 & 0.370 & 0.330 & 0.331 & 0.512 & 0.759 & 0.533 & 0.000 \\
\hline \multirow[t]{6}{*}{$8-\mathrm{FP}$} & FP_1 & 0.396 & 0.292 & 0.386 & 0.317 & 0.291 & 0.360 & 0.435 & 0.797 & 0.000 \\
\hline & FP_2 & 0.413 & 0.353 & 0.376 & 0.319 & 0.336 & 0.414 & 0.524 & 0.805 & 0.000 \\
\hline & FP_3 & 0.404 & 0.385 & 0.372 & 0.341 & 0.303 & 0.413 & 0.516 & 0.810 & 0.000 \\
\hline & FP_4 & 0.246 & 0.275 & 0.153 & 0.184 & 0.135 & 0.126 & 0.440 & 0.594 & 0.000 \\
\hline & FP_5 & 0.278 & 0.265 & 0.270 & 0.212 & 0.202 & 0.240 & 0.570 & 0.633 & 0.000 \\
\hline & FP_6 & 0.346 & 0.205 & 0.235 & 0.231 & 0.175 & 0.230 & 0.521 & 0.636 & 0.000 \\
\hline
\end{tabular}


Leveraging Firm Performance Through Information Technology Strategic Alignment and Knowledge Management Strategy: An Empirical Study of It-Business Value

\section{SOURCES OF FUNDING}

This research received no specific grant from any funding agency in the public, commercial, or not-for-profit sectors.

\section{CONFLICT OF INTEREST}

The author have declared that no competing interests exist.

\section{ACKNOWLEDGMENT}

None.

\section{REFERENCES}

[1] Albertin, A. L., \& Albertin, R. M. M. (2012). Dimensions of the use of information technology: a diagnostics and analysis instrument. Journal of Business Administration, 46(1), 125-151.

[2] Al-Ammary, J. (2014). The strategic alignment between knowledge management and information systems strategy: The impact of contextual and cultural factors. Journal of Information \& Knowledge Management, 13(1), 1450006.

[3] Andriani, M., Samadhi, T.M.A.A., Siswanto, J. and Suryadi, K. (2019), 'Knowledge management strategy: an organisational development approach', Business Process Management Journal, Vol. 25 No. 7, pp. 1474-1490.

[4] Aral, S., \& Weill, P. (2007). IT assets, organizational capabilities, and firm performance: How resource allocations and organizational differences explain performance variation. Organization Science, 18(5), pp. 763-780

[5] Arnott, D., \& Pervan, G. (2014). A critical analysis of decision support systems research revisited: The rise of design science. Journal of Information Technology, 29(4), 269-293.

[6] Aydiner, A.S., Tatoglu, E., Bayraktar, E. and Zaim, S. (2019a), 'Information system capabilities and firm performance: Opening the black box through decision-making performance and business-process performance', International Journal of Information Management, Elsevier, Vol. 47 No. July 2018, pp. 168-182.

[7] Aydiner, A.S., Tatoglu, E., Bayraktar, E., Zaim, S. and Delen, D. (2019b), 'Business analytics and firm performance: The mediating role of business process performance', Journal of Business Research, Elsevier, Vol. 96 No. October 2018, pp. 228-237

[8] Bolisani, E. and Bratianu, C. (2017), 'Knowledge strategy planning: an integrated approach to manage uncertainty, turbulence, and dynamics', Journal of Knowledge Management, Vol. 21 No. 2, pp. 233-253.

[9] Caputo, F., Garcia-Perez, A., Cillo, V. and Giacosa, E. (2019), 'A knowledge-based view of people and technology: directions for a value co-creation-based learning organisation', Journal of Knowledge Management, Vol. 23 No. 7, pp. 1314-1334

[10] Chatterjee, S., Moody, G., Lowry, P.B., Chakraborty, S. and Hardin, A. (2020), 'Information Technology and organizational innovation: Harmonious information technology affordance and courage-based actualization', Journal of Strategic Information Systems, Elsevier, Vol. 29 No. 1, p. 101596.

[11] Chen, L (2010). Business-IT alignment maturity of companies in China. Information \& Management, 47(1), 9 16.

[12] Chin, W. W. (1998). The partial least squares approach for structural equation modeling. In G. A. Marcoulides (Ed.), Modern methods for business research (pp. 295-236). London: Lawrence Erlbaum Associates.

[13] Chin, W. W., Thatcher, J. B., Wright, R. T., \& Steel, D. (2013). Controlling for common method variance in PLS analysis: the measured latent marker variable approach. In H. Abdi \& W. W. Chin (Eds.), New perspectives in partial least squares and related methods (pp. 231-239). New York: Springer.

[14] Coltman, T. R., Tallon, P. P., Sharma, R., \& Queiroz, M. (2015). Strategic IT alignment: Twenty-five years on. Journal of Information Technology, 30, 91-100. 
[15] Davenport, T. H., \& Harris, J. G. (2007). Competing on analytics: The new science of winning. Cambridge, MA: Harvard Business Press.

[16] Davenport, T., Harris, J., \& Morison, R. (2010). Analytics at work: Smarter decisions, better results. Boston: Harvard Business Review.

[17] Gerow, J. E., Thatcher, J. B., \& Grover, V. (2015). Six types of IT-business strategic alignment: An investigation of the constructs and their measurement. European Journal of Information Systems, 24(5), 465-491.

[18] Grant, R. M. (2010). Contemporary strategy analysis and cases: Text and cases. New York: John Wiley \& Sons.

[19] Hair Jr., J. F., Hult, G., Ringle, C., \& Sarstedt, M. (2013). A primer on partial least squares structural equation modeling (PLS-SEM). Thousand Oaks, CA: Sage.

[20] Henderson, J. C., and Venkatraman, N. (1999) Strategic alignment: Leveraging information technology for transforming organizations. IBM Systems Journal, 38(2/3), 472-484.

[21] Henseler, J., Ringle, C. M., Sinkovics, R. R (2009). The use of partial least squares path modeling in international marketing. Advances in International Marketing, 20, 277-319.

[22] Jami Pour, M., Kouchak Zouchak., Z. and Ahmad Zadeh, N. (2018), 'Designing an integrated methodology for knowledge management strategic planning: The roadmap toward strategic alignment', VINE Journal of Information and Knowledge Management Systems, Vol. 48 No. 3, pp. 373-387.

[23] Kaplan, R. S., \& Norton, D. P. (2000). The strategy-focused organization: How balanced scorecard companies thrive in the new business environment. Boston: Harvard Business School Press.

[24] Kim, G., Shin, B., Kim, K. K., \& Lee, H. G. (2011). IT Capabilities, Process-Oriented Dynamic Capabilities, and Firm Financial Performance. Journal of the Association for Information Systems, 12(7), 487.

[25] Kohli, R., \& Grover, V. (2008). Business value of IT: An essay on expanding research directions to keep up with the times. Journal of the Association for Information Systems, 9(1), 23-39.

[26] Li, T. and Chan, Y. E. (2019) 'Dynamic information technology capability: Concept definition and framework development', Journal of Strategic Information Systems. Elsevier, 28(4), p. 101575. doi: 10.1016/j.jsis.2019.101575.

[27] Maçada, A. C. G., Beltrame, M. M., Dolci, P. C., \& Becker J. L. (2012). IT Business value model for information intensive organizations. Brazilian Administration Review, 9(1), 44-65.

[28] Malhotra, N. K. (2006). Pesquisa de marketing: Uma orientação aplicada (4th ed.). Porto Alegre: Bookman.

[29] Marôco, J. (2010). Análise de equações estruturais: Fundamentos teóricos, software e aplicações. São Paulo: Pêro Pinheiro.

[30] Martelo-Landroguez, S. and Cepeda-Carrión, G. (2016), 'Knowledge Management Research \& Practice', Knowledge Management Research and Practice, Vol. 14 No. 4, pp. 423-433.

[31] Melville, N., Kraemer, K., \& Gurbaxani, V. (2004). Information technology and organizational performance: An integrative model of IT business value. MIS Quarterly, 28(2), 283-322.

[32] Mikalef, P., Krogstie, J., Pappas, I.O. and Pavlou, P. (2019), 'Exploring the relationship between big data analytics capability and competitive performance: The mediating roles of dynamic and operational capabilities', Information and Management, Elsevier, No. February 2018, p. 103169.

[33] Mikalef, P. and Pateli, A. (2017), 'Information technology-enabled dynamic capabilities and their indirect effect on competitive performance: Findings from PLS-SEM and fsQCA', Journal of Business Research, Elsevier B.V., Vol. 70, pp. 1-16.

[34] Nitzl, C., \& Hirsch, B. (2014). When do managers trust their management accountants? Retrieved from http://ssm.com/abstract 2127701

[35] Nonaka, I., \& Toyama, R. (2005). The theory of the knowledge creation firm: Subjectivity, objectivity, and synthesis. Industrial and Corporate Change, 14(3), 419-436.

[36] Nonaka, I., Von Krogh, G., \& Voelpel, S. (2006). Organizational knowledge creation theory: Evolutionary paths and future advances. Organization studies, 27(8), 1179-1208.

[37] Nguyen, T.N.Q., Ngo, L.V., Northey, G. and Siaw, C.A. (2019), 'Realising the value of knowledge resources and capabilities: an empirical study', Journal of Knowledge Management, Vol. 23 No. 2, pp. 374-395.

[38] Queiroz, M., Tallon, P. P., Sharma, R., \& Coltman, T. (2018). The role of IT application orchestration capability in improving agility and performance. Journal of Strategic Information Systems, 27(1), 4-21. https://doi.org/10.1016/j.jsis.2017.10.002

[39] Porter, M. (1996). What is strategy. Harvard Business Review, 74(6), 61-78. 
Leveraging Firm Performance Through Information Technology Strategic Alignment and Knowledge Management Strategy: An Empirical Study of It-Business Value

[40] Ramdani, B. (2012). Information technology and organisational performance: Reviewing the business value of IT literature. In Y. K. Dwivedi, M. R. Wade, \& S. L. Schneberger (Eds.), Information systems theory: Explaining and predicting our digital society (Vol. 1). New York: Springer.

[41] Ringle, C. M., Wende, S., \& Will, A. (2005). Smart PLS 2.0 M3. Hamburg, Germany: University of Hamburg. Retrieved March 16, 2017, from http://www.smartpls.de.

[42] Ringle, C., Silva D., \& Bido, D. S. (2014). Structural equation modeling with SMARTPLS. REMark, 13, 54-71.

[43] Shujahat, M., Hussain, S., Javed, S., Malik, M.I., Thurasamy, R. and Ali, J. (2017), 'Strategic management model with lens of knowledge management and competitive intelligence: A review approach', VINE Journal of Information and Knowledge Management Systems, Vol. 47 No. 1, pp. 55-93.

[44] Taher, M. (2012), 'Resource-Based View Theory', in Dwivedi, Y.K., Wade, M.R. and Schneberger, S.L. (Eds.), Information Systems Theory: Explaining and Predictin Our Digital Society. Vol. 1. Integrated Series in Information Systems 28, Spring New York Dordrecht Heidelberg London, New York, NY, pp. 151-163.

[45] Tallon, P. P. (2008). A process-oriented perspective on the alignment of information technology and business strategy. Journal of Management Information Systems, 24(3), 231-272.

[46] Tallon, P. P., \& Pinsonneault, A. (2011). Competing perspectives on the link between strategic information technology alignment and organization agility: Insights from a mediation model. MIS Quarterly, 35(2), 463486.

[47] Tallon, P., Queiroz, M., Coltman, T., \& Sharma, R. (2016). Business Process and Information Technology Alignment: Construct Conceptualization, Empirical Illustration, and Directions for Future Research. Journal of the Association for Information Systems, 17(9), 563-589. https://doi.org/10.17705/1jais.00438

[48] Tallon, P. P., Queiroz, M., Coltman, T., \& Sharma, R. (2019). Information technology and the search for organizational agility: A systematic review with future research possibilities. Journal of Strategic Information Systems, 28(2), 218-237. https://doi.org/10.1016/j.jsis.2018.12.002

[49] Tarhan, A., Turetken, O., \& Reijers, H. (2015, May). Do mature business processes lead to improved performance? A review of literature for empirical evidence. Association for Information Systems.

[50] Zack, M. H. (1999). Developing a knowledge strategy. California management review, 41(3), 125-145.

[51] Zaim, H., Muhammed, S. and Tarim, M. (2019), 'Relationship between knowledge management processes and performance: critical role of knowledge utilization in organizations', Knowledge Management Research and Practice, Taylor \& Francis, Vol. 17 No. 1, pp. 24-38.

[52] Wolf, C. and Floyd, S. W. (2017) 'Strategic Planning Research: Toward a Theory-Driven Agenda', Journal of Management, 43(6), pp. 1754-1788. doi: 10.1177/0149206313478185

[53] Yayla, A. A. and $\mathrm{Hu}, \mathrm{Q}$. (2012). The impact of IT-business strategic alignment on firm performance in a developing country setting: Exploring moderating roles of environmental uncertainty and strategic orientation. European Journal of Information Systems, 21(4), 373-387.

[54] Xue, L., Ray, G., \& Sambamurthy, V. (2012). Efficiency or innovation: How do industry environments moderate the effects of firms' IT asset portfolios? MIS Quarterly, 36(2), 509-528.

[55] Yoshikuni, A. C., \& Albertin, A. L. (2014). Model analysis of the relationship between strategic organization knowledge and the use of information systems in firm performance in Brazil. Chinese Business Review, 13(5), 301-319.

[56] Yoshikuni, A. C., \& Albertin, L. A. (2017). IT-Enabled Dynamic Capability on Performance: an Empirical Study of BSC Model. Journal of Business Management,5(May/June), 215-231

[57] Yoshikuni, A.C. and Albertin, A.L. (2018), 'Effects of strategic information systems on competitive strategy and performance', International Journal of Productivity and Performance Management, Vol. 67 No. 9, pp. 2018-2045. 